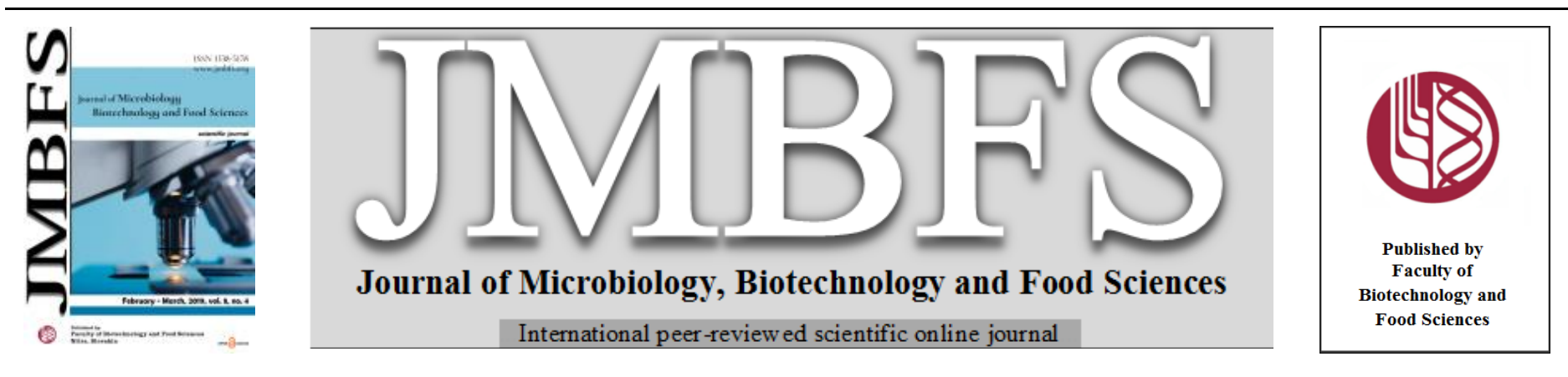

\title{
THE INFLUENCE OF MICROBIAL PREPARATION ON THE MIGRATION OF WATER SOLUBLE FORMS OF COPPER IN SOIL-PLANT SYSTEM AND GRAIN QUALITY OF WINTER WHEAT
}

\author{
Lyudmila Chaikovska ${ }^{1,3}$, Olga Ovsienko ${ }^{1}$, Marina Baranskaya ${ }^{1}$, Valentina Klyuchenko², Nina Klimenko ${ }^{2}$
}

Address(es): Lyudmila Chaikovska,

${ }^{1}$ Research Institute of Agriculture of Crimea, Department of Agricultural Microbiology, str. Kyevskaya 150, 95000 Simferopol, Crimea, +7(978)852 18 63.

${ }^{2}$ Agroindustrial College of V.I.Vernadsky Crimean University, Studencheskaya str. 1, 97517 Simferopol district, v. Malenkoe, Crimea.

${ }^{3}$ Academy of Life and Environmental Science of V.I.Vernadsky Crimean University, 95000 v. Agrarnoe.

*Corresponding author: ludachaika@mail.ru

doi: 10.15414/jmbfs.2019.8.4.1103-1105

\section{ARTICLE INFO}

Received 31. 5. 2018

Revised 15. 1. 2019

Accepted 15. 1. 2019

Published 1. 2. 2019

Regular article

open $\partial_{\text {ACCESS }}$

\begin{abstract}
One of the most dangerous and most widespread chemical pollutions of the biosphere are heavy metals (HM). Therefore, the assessment of their biogenic migration in the "soil-plant" system and the search for ways to reduce toxic effects on the environment are priority and relevant. The task of our researches consisted of the determination of influence the microbial preparation Phosphoenterin on the migration of water soluble forms of copper in the soil-plant system and grain quality (protein and gluten content) at growing winter wheat under the conditions of model field experiments. The quantitative content of water soluble forms of copper in soil samples (chernozem southern calcareous) and plants (roots, straw, grain) by atomic absorption analysis has been obtained. The content of gluten and protein in the grain of winter wheat was determined by infrared spectroscopy. The positive effect of the microbial preparation Phosphoenterin on the migration of water soluble forms of copper in the soil-plant system was established. In the rhizosphere of inoculated plants their accumulation decreased by $29-39 \%$, roots $-7-28 \%$, straw $-7-39 \%$, grain $-6-40 \%$ in comparison to the control variant. Correlation analysis showed the presence of direct, close, reliable relationships between the content of water soluble $\mathrm{Cu}$ compounds in the rhizosphere, roots, straw and winter wheat grain $(r=0.89-0.98)$. The positive effect of presowing inoculation of seeds on the quality (protein and gluten content increased to $15 \%$ and $28 \%$ against $13 \%$ and $24 \%$ on the control variant, respectively) of grain winter wheat, growing on a natural background has been showed.
\end{abstract}

Keywords: Phosphoenterin, winter wheat, water soluble copper compounds, rhizosphere

\section{INTRODUCTION}

Heavy metals (HM) play a priority role in modern environmental pollution processes. The ways of their arrival in natural and agroecosystems are different: emissions of factories, plants, vehicles, the use of plant protection chemicals, etc. As a rule, HM have high biochemical activity. Some of them play a significant role in metabolism, being important trace elements for animals and plants ( $\mathrm{Fe}$, $\mathrm{Cu}, \mathrm{Co}, \mathrm{Mo}$, etc.). However, the organisms need for most of them is small and is expressed by micrograms, and in large quantity they become toxicants. The danger of HM is also compounded by their ability to accumulate in organisms and concentrate in food chains. As a result, HM, in particular copper, accumulate in the soil and hydrosphere, and also migrate to plants grown in contaminated areas. To reduce the toxic effect of HM in agrophytocenosis is possible in the transition to biological farming, one of which methods is the use of environmentally friendly microbial preparations (Tikhonovich et al., 2011; Zavalin et al., 2010). It is known, that the economically useful microorganisms, included in their composition, improve the growth and nutrition of crops, and also have protective properties against pests and stress (Belimov, 2008; Belimov et al., 2011). Thus, a number of researchers have shown the ability of microbial agents to convert plant-toxic forms of HM into less toxic insoluble complexes (Arkchipova et al., 2004; Belogolova et al., 2011, 2013). It is known that some associative bacteria have the ability to significantly improve the condition of plants on soils contaminated with TM. This is due to their excretion of growth substances that accelerate the development of plants and enhance their absorption of nutrients compounds (Dodd et al., 2010). In addition, bacteria can mobilize of HM ions and prevent their accumulation in plant cells (Safronova et al., 2006).

The task of our researches consisted to determination of the effect of microbial preparations (for example Phosphoenterin) on the migration of water soluble forms of copper in the soil-plant system and qualitative indices of grain (protein and gluten content) at the cultivation of winter wheat in the conditions of model field experiments.

\section{MATERIALS OF RESEARCHES}

Field experiments were conducted at the experimental plot of the Crimean Agroindustrial College (Simferopol district) in 2012-2014. The Soil - Chernozem southern calcareous. Agrochemical characteristics of soil: humus content $-2.5 \%$; mobile forms of nitrogen and phosphorus -5.3 and $2.6 \mathrm{mg} / 100 \mathrm{~g}$ of soil, respectively; $\mathrm{pH}$ of water extraction - 7.0-7.2. The area of the cultivated plots was $10 \mathrm{~m}^{2}$, accounting $-5 \mathrm{~m}^{2}$, placed randomly; repetition of experiment fourfold. In early spring, $\mathrm{CuSO}_{4}$ solution was introduced into the soil from calculations (according to $\mathrm{Cu}$ content) corresponding to the pollution levels: 5, 10 and $20 \mathrm{MPC}$ (for soils $6 \mathrm{mg} / \mathrm{kg}$ ). In the control variants, no $\mathrm{CuSO}_{4}$ solution was introduced. Microbial preparation Phosphoenterin, created on the basis of phosphate mobilizing bacterium Enterobacter nimipressuralis 32-3 (Chaikovska, 2011; Chaikovska et al., 2006, Chaikovskaya et al., 2017), was used for presowing inoculation of wheat seeds; the seeds were moistened with water in the control.

\section{METHODS OF RESEARCHES}

Determination of the quantitative content of water-soluble forms of copper in soil and plants (grain) was carried out by atomic absorption analysis according to the guidelines of GOST (GOST, 1998, 2010; RD, 1991). The content of gluten and protein in grain is determined by infrared spectroscopy (DSTU, 2007). Field experiments and statistical processing of the obtained data were carried out in accordance with the generally accepted methods (Dospekhov, 1985) and the program Statistica 7.0 (Bureeva, 2007; Meshalkina 2008).

\section{RESULTS AND DISCUSSION}

The analysis of the results showed a small background content of water-soluble forms of copper in the soil of experimental plots: it did not exceed the permissible values of maximum permissible concentration (MPC) for soils and 
constituted $0.5-0.6 \mathrm{mg} / \mathrm{kg}$. It is necessary to note, that these data are in accordance with the results established by other authors for arable soils of the Crimea (Sychevskiy et al., 2012).

Our results is evidence, that depending on the level of contamination of soil, in the rhizosphere of wheat accumulated a significant amount of water-soluble compounds of copper: in the range of $18.6-97.6 \mathrm{mg} / \mathrm{kg}$. Thus, by contamination of the soil at 5, 10 and $20 \mathrm{MPC}$, their content in the rhizosphere amounted to $18.6,45.4$ and $97.6 \mathrm{mg} / \mathrm{kg}$, respectively. Results are shown in the figure 1 .

It was found, that the use of Phosphoenterin for presowing inoculation of wheat seeds allowed to reduce the concentration of water-soluble forms of $\mathrm{Cu}$ in the rhizosphere of inoculated plants in comparison to the control variant. Thus, in according to the results, their contents decreased by $29-39 \%$ against control at every level of soil pollution and amounted to $13.1,30.2$ and $64.2 \mathrm{mg} / \mathrm{kg}$ at 5,10 and $20 \mathrm{MPC}$, respectively.

It is known that for migration of HM in the soil-plant system is influenced by many factors: physical and chemical properties of soils, their biological activity, as well as physiological mechanisms of different plant species. These factors may determine the general form and ability of HM transfer in the soil-plant system (Zheng et al., 2015 ). In the literature there is information, that the primary source of HM in wheat plants are heavy metals contained in the soil (Wu et al. 2013; Xue et al., 2014)

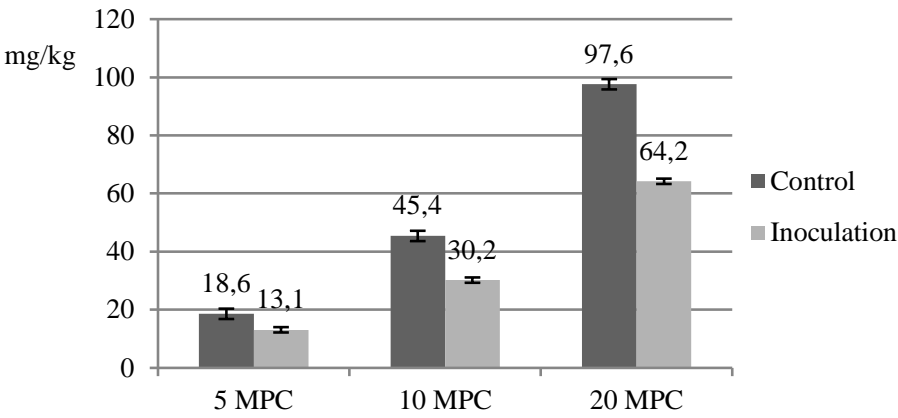

Figure 1 Content of water soluble copper compounds in the rhizosphere of winter wheat $(\mathrm{mg} / \mathrm{kg})$

The results of our studies showed, that in the roots of plants of the control variant growing in the background area, the content of water-soluble compounds $\mathrm{Cu}$ was $6.0 \mathrm{mg} / \mathrm{kg}$, and in the roots of plants grown on plots contaminated TM - varied within 7.3-31.9 mg / kg (Tab. 1). It was found that the accumulation of watersoluble forms of copper in wheat straw was significantly less than in the roots $(3.0-3.8 \mathrm{mg} / \mathrm{kg})$ : twice - in the background areas and with pollution at the level of 5 MPC. At high levels of soil contamination (10 MPC and $20 \mathrm{MPC}$ ), the content of water-soluble $\mathrm{Cu}$ compounds in straw reached $4.4-8.9 \mathrm{mg} / \mathrm{kg}$ : $3-4$ times less than in wheat roots.

Table 1 Content of water-soluble copper compounds in winter wheat phytomass (mg/ kg)

\begin{tabular}{|c|c|c|}
\hline Variants & Roots & Straw \\
\hline \multicolumn{3}{|c|}{ Background (less HM) } \\
\hline Control & 6.0 & 3.0 \\
\hline Inoculation & 5.1 & 2.7 \\
\hline$L S D_{05}$ & 2,60 & 2,35 \\
\hline \multicolumn{3}{|c|}{$5 \mathrm{MPC}$} \\
\hline Control & 7.3 & 3.8 \\
\hline Inoculation & 6.2 & 3.1 \\
\hline$L S D_{05}$ & 1,96 & 1,69 \\
\hline \multicolumn{3}{|c|}{$10 \mathrm{MPC}$} \\
\hline Control & 20.1 & 4.4 \\
\hline Inoculation & 18.5 & 4.1 \\
\hline$L S D_{05}$ & 4,97 & 1,72 \\
\hline \multicolumn{3}{|c|}{$20 \mathrm{MPC}$} \\
\hline Control & 31.9 & 8.9 \\
\hline Inoculation & 23.0 & 5.5 \\
\hline$L S D_{05}$ & 8,98 & 1,35 \\
\hline
\end{tabular}

Legend: LSD 05 -Least Significant Difference at 5\% significance level

The use of Phosphoenterin for seed-presowing inoculation of wheat contributed to the reduction of water-soluble copper compounds not only in the rhizosphere, but also their migration to the roots and straw. Thus, the accumulation of $\mathrm{Cu}$ compounds in the roots of inoculated plants decreased by $7-28 \%$, in straw - by 7 $39 \%$ in comparison to the control variant (plants grown from seeds without inoculation).

According to the results of our research, the content of water-soluble copper compounds in the rhizosphere of winter wheat on natural background and plot with different levels of soil pollution significant fluctuations has been reached. However, despite this, their accumulation in the grain was within $1.0-5.2 \mathrm{mg} / \mathrm{kg}$, which did not exceed the MPC (for grain $10 \mathrm{mg} / \mathrm{kg}$ ). It should be noted the positive influence of Phosphoenterin on the content of water-soluble compounds of $\mathrm{Cu}$ in the grain of inoculated plants: it was lower than in the control (by 6$40 \%$, depending on the variant) and varied within $0.6-4.9 \mathrm{mg} / \mathrm{kg}$ (Figure 2).

The results of our research confirmed the data obtained by other authors. Thus, in the study of TM accumulation in various parts of winter wheat was founded the largest content of them to accumulated in the roots and the least - in the grain (Wang et al., 2016)

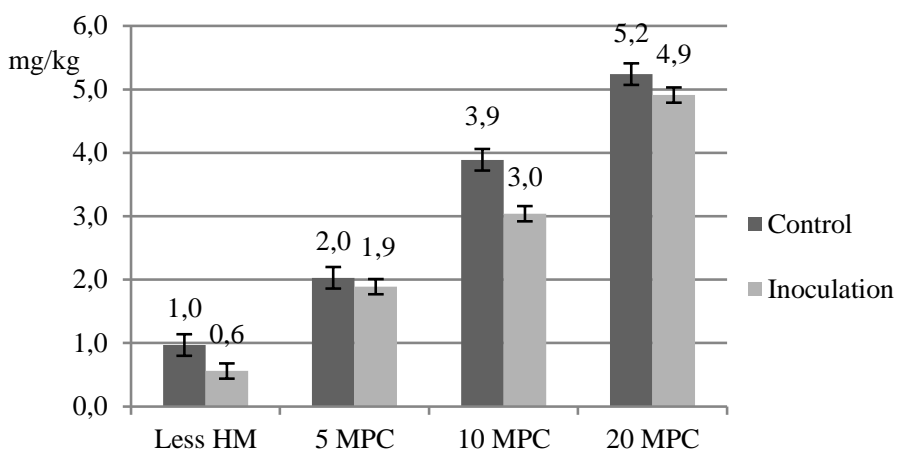

Figure 2 Content of water-soluble copper compounds in winter wheat grain (mg $/ \mathrm{kg})$

The correlation analysis to determine the dependence of the content of watersoluble forms of copper in the rhizosphere and various parts of winter wheat plant has been carried. The obtained data showed (Tab. 2), that in variants without using Phosphoenterin a direct, close and reliable relationship between $\mathrm{Cu}$ content in soil, roots, straw and grain of winter wheat has been established $(\mathrm{r}=0,89-0,98)$

Table 2 Correlation coefficients between indices of water-soluble $\mathrm{Cu}$ compounds in the soil and in the investigated parts of plants of winter wheat (without the use of Phosphoenterin)

\begin{tabular}{lcccc}
\hline & Soil & Roots & Straw & Grain \\
\hline Soil & - & & & \\
\hline Roots & 0,98 & - & & \\
\hline Straw & 0,97 & 0,93 & - & - \\
\hline Grain & 0,97 & 0,98 & 0,89 & \\
\hline
\end{tabular}

The use of the microbial preparation Phosphoenterin for seed-presowing inoculation contributed to the reduction of the content of water-soluble coppe compounds in the rhizosphere and various parts of winter wheat, which is also proved by the direct close connection in the correlation analysis (Tab. 3).

Thus, it can be maintain, that with increase in the $\mathrm{Cu}$ content in the rhizosphere of winter wheat, occurred increase of content this element in the rest parts of wheat plants both with and without inoculation.

Table 3 Correlation coefficients between the content of water-soluble $\mathrm{Cu}$ compounds in the soil and the studied parts of the plant (presowing inoculation)

\begin{tabular}{|c|c|c|c|c|}
\hline & Soil & Roots & Straw & Grain \\
\hline Soil & - & & & \\
\hline Roots & 0,94 & - & & \\
\hline Straw & 0,98 & 0,95 & - & \\
\hline Grain & 0,99 & 0,94 & 0,97 & - \\
\hline
\end{tabular}

Thus, the correlation analysis showed the presence of direct, close, reliable relationships between the content of water-soluble $\mathrm{Cu}$ compounds in the rhizosphere, roots, straw and winter wheat grain $(\mathrm{r}=0.89-0.98)$. The positive effect of the microbial preparation Phosphoenterin (presowing inoculation of winter wheat seeds) on the migration of water-soluble forms of $\mathrm{Cu}$ in the soilplant system was established. In the rhizosphere of inoculated plants their accumulation decreased by $29-39 \%$, roots-by $7-28 \%$, straw - by $7-39 \%$, grain by $6-40 \%$ in comparison to the control variant.

It is known, that one of the most important indicators of grain quality is the content of protein and gluten. The results indicate that use of Phosphoenterin for seeds-presowing inoculation contributed to the increase in protein content in wheat grain, growing in plots of natural background: up to $15.2 \%$ against $13.4 \%$ in the control (Tab. 4). There were no significant effects of seed-presowing inoculation on protein content in wheat grain, growing on contaminated $\mathrm{CuSO}_{4}$ plots. 
Table 4 - Effect of inoculation on quality indicators of winter wheat grain at different levels of soil pollution

\begin{tabular}{lcc}
\hline \multirow{2}{*}{ Variants } & \multicolumn{2}{c}{ Contents, \% } \\
\cline { 2 - 3 } & Protein & Gluten \\
\hline Control (less HM) & & 23.9 \\
\hline Control & 13.4 & 28.4 \\
\hline Inoculation & 15.2 & \\
\hline HM (5 MPC) & & 25.0 \\
\hline Control & 12.8 & 25.3 \\
\hline Inoculation & 12.7 & 24.8 \\
\hline HM (10 MPC) & & 28.2 \\
\hline Control & 12.0 & 25.4 \\
\hline Inoculation & 12.9 & 25.1
\end{tabular}

The positive effect of presowing inoculation of seeds on the increase of gluten content in winter wheat grain grown on the natural background plots also has been established: up to $28.4 \%$ against $23.9 \%$ on the control variant. In addition, it is necessary to note the positive impact Phosphoenterin on the amount of gluten in wheat grain when the soil contamination at the level of $10 \mathrm{MPC}$ : it increased to $28.2 \%$ (against $24.8 \%$ in the variant without inoculation)

Thus, the positive effect of presowing inoculation of seeds on the main indicators of quality of winter wheat grain (protein and gluten content increased to $15.2 \%$ and $28.4 \%$ against $13.4 \%$ and $23.9 \%$ under control, respectively), growing on the natural background areas. There was no significant influence of presowing inoculation of seeds on the protein and gluten content in wheat grain grown on contaminated $\mathrm{CuSO}_{4}$ plots.

According to obtained results, the use of the microbial preparation Phosphoenterin also showed a positive effect on the grain productivity of winte wheat: it increased on average in three years compared to the control by $0.16 \mathrm{t} / \mathrm{h}$ $(6.4 \%)$ in the natural background areas and by $0.25-0.38 \mathrm{t} / \mathrm{ha}(12 \%-22 \%)$ in soil contamination plots.

\section{CONCLUSIONS}

1. The positive effect of the microbial preparation Phosphoenterin on the migration of water soluble forms of $\mathrm{Cu}$ in the soil-plant system at cultivated of winter wheat under the conditions of model field experiments has been established. The accumulation of water soluble forms of $\mathrm{Cu}$ in the rhizosphere of inoculated plants decreased by $29-39 \%$.

2. The correlation analysis showed the presence of direct, close, reliable links between the content of water soluble $\mathrm{Cu}$ compounds in the rhizosphere, roots, straw and winter wheat grain $(r=0.89-0.98)$.

3. The positive influence of Phosphoenterin on grain quality indicators of winter wheat showed: protein and gluten contents increased to $15 \%$ and $28 \%$ against $13 \%$ and $24 \%$ in control variant accordingly.

\section{REFERENCES}

ARKHIPOVA, T.N., MELENT'EV, A.I., VESELOV, S.YU., KUDOYAROVA G.R. 2004. The Influence of Cytokinin-producing Microorganisms on the Tolerance of Lettuce Plants to Cadmium Stress. Agrochemistry, 3, 69 -73.

BELIMOV, A.A. 2008. Interaction of associative bacterium and plants depending on biotic and abiotic factors: Author's abstr. of dis. .... doctor biol sciences. S-Pb: Publishing house of S-PbSU, 45.

BELIMOV,A.A., TIKHONOVICH, I.A. 2011. Microbiological aspects of resistance and accumulation of heavy metals by plants.Agricultural biology, 3 , $10-15$.

BELOGOLOVA, G.A., SOKOLOVA, M.G., GORDEYEVA O.N. 2013. Migration and Bio-Accessibility of Heavy Metals, Arsenic and Phosphorus: the Impact of Rhizospheric Bacteria in Technogenic-Polluted Ecosystems. Agrochemistry, 6, 69-77.

BElOGOlOVA, G.A., SOKOlOVA, M.G., PROIYDAKOVA, O.A. 2011 Effect of soil bacteria on the distribution of chemical elements in the soil-plant system.Agrochemistry, 9, 89-97.

BUREEVA, N.N. Multidimensional statistical analysis using the "STATISTICA" RFP. Educational and methodological material on the program of advanced training "Application of software in scientific research and teaching of mathematics and mechanics".Nizhny Novgorod, 2007, 112 p.

CHAIKOVSKA, L. A. [et al.]. 2006. Fertilizing biopreparation "Phosphoenterin" on the basis of phosphat mobilizing strain of the bacteria Enterobacter nimipressuralis 32-3. The Declaration patent of Ukraine for useful model 12537. Application 2005 07621, decision dated 10.11.05.Bull. 2, 8.

CHAIKOVSKA, L. A. 2011.The research on phosphate mobilizing bacteria from soils of Southern Ukraine. Journal of Life Sciences, 5, 509-512.

CHAIKOVSKAYA, L.A., BARANSKAYA, M.I. 2017.The Mechanism of Action of Rhizobacteria Enterobacter nimipressuralis 32-3 on the Mineral Nutrition and Productivity of Soybean.Annual Research \& Review in Biology, 14.DOI :10.9734/ARRB/2017/33934
DODD I.C., BELIMOV A.A. 2010. Rhizobacterial impacts on plant water use efficiency // Aspects of applied biology, 105.

DOSPEKHOV, B.A. 1985. Principles of field experiment (and basis of statistical treatment of researches results).M.:Agropromizdat, $351 \mathrm{p}$.

GOST 26929-94. 2010. Raw materials and food. Sample preparation.Mineralization to determine the content of toxic elements.

GOST 30178-96. 1998. Raw materials and food. Atomic absorption method for determination of toxic elements.

Grain and products of their treatment. Determination of quality indices by method of infrared spectroscopy: DSTU 4217:2007 - DSTU 4117. K.:Statconsumstandard of Ukraine. $-2007 .-8 \mathrm{p}$.

MESHALKINA, J. L., SAMSONOVA,V.P. Mathematical statistics in soil science: Practical work.-M.: MAKSPress, 2008. - 84 p.

RD 52.18.289-90. 1991. Methodical instructions. Methods of measurement of the mass fraction of mobile forms of metals (copper, lead, zinc, nickel, cadmium, cobalt, chromium, manganese) in soil samples by atomic absorption analysis, 1991.

SAFRONOVA V.I., STEPANOK V.V., ENGQVIST G.L., ALEKSEEV Yu.V., BELIMOV A.A. 2006. Root-associated bacteria containing 1aminicyclopropane-1carboxylate deaminase improve growth and nutrient uptake by pea genotypes cultivated in cadmium supplemented soil // Biology and Fertility of Soils, 42. p. 267-272.

SYCHEVSKIY, M.E., VINNIK, A.L., SVYATYUK, YU.V. 2012. Dynamics of the content of mobile forms of heavy metals in the soils of the Crimea under the influence of 45-year-old application of mineral fertilizers. Agroecologichnyi zhurnal, 3,111-114.

TIKHONOVICH, I.A., PROVOROV, N.A. 2011. Agricultural microbiology as the basis of ecologically sustainable agriculture: fundamental and applied aspects. Agricultural biology, 3, 3-9.

WANG, X.R., ZHON, S.L., WU, S.H. 2016. Accumulation of Heavy Metals in Different Parts of Wheat Plant from Yangtze River Delta, China.Int. J. Agric. Biol., 18, 1242-1248.

WU, S.L., ZHANG, X., CHEN, B.D. 2013. Effects of arbuscular mycorrhiza fungi on heavy metal translocation and transformation in soil - plant continuum. Asian. J. Ecotoxicol, 8, 847-856.

XUE, Y., WANG,Y.Y., YAO, Q.H, SONG, K., ZHENG X.Q. 2014. Research progress in plants resistance to heavy metal $\mathrm{Cd}$ in soil.Ecol. Environ. Sci., 23 , 528-534.

ZAVALIN, A.A. 2010. New technologies of promotion and application of biopreparations with complex impact. S-Pb: CHIMIZDAT, 64.

ZHENG, H.Y., YAO, X.R., HOU, Y.L. 2015. Establishment of Heavy Meta Bioaccumulation Model of Soil Pattern-Crop System in China. J. Agro-Eviron. Sci., 34, 257-265. 